\title{
Clinical Value of Two Detection Methods for Mycoplasma Pneumoniae Antibody in the Diagnosis of Mycoplasma Pneumoniae Infection in North China
}

\section{Jupeng Wang}

Tianjin Medical University Cancer Institute and Hospital: Tianjin Tumor Hospital

\section{Lina Zhu}

Second Affiliated Hospital of Tianjin University of Traditional Chinese Medicine

\section{Mingkun Ma}

Second Affiliated Hospital of Tianjin University of Traditional Chinese Medicine

Hui Chen

Second Affiliated Hospital of Tianjin University of Traditional Chinese Medicine

\section{Suxiang Guo}

Second Affiliated Hospital of Tianjin University of Traditional Chinese Medicine

\section{Guangye Wu}

Second Affiliated Hospital of Tianjin University of Traditional Chinese Medicine

\section{Shaohong Li}

Second Affiliated Hospital of Tianjin University of Traditional Chinese Medicine

\section{Xuehong Wen}

Second Affiliated Hospital of Tianjin University of Traditional Chinese Medicine

\section{Li Ren ( $\square$ liren@tmu.edu.cn )}

Tianjin Medical University Cancer Institute and Hospital: Tianjin Tumor Hospital https://orcid.org/0000-0002-8928-6003

\section{Research}

Keywords: Mycoplasma pneumoniae, community-acquired pneumonia, particle agglutination, indirect immunofluorescence assay

Posted Date: September 30th, 2021

DOI: https://doi.org/10.21203/rs.3.rs-934275/v1

License: (c) (1) This work is licensed under a Creative Commons Attribution 4.0 International License. Read Full License 


\section{Abstract}

Background: To analyze the detection of Mycoplasma pneumoniae in adults and children in North China using two antibody detection methods, and to guide prevention and treatment.

Methods: A retrospective study was conducted from September 2017 to May 2021. Mycoplasma pneumoniae total antibody was detected using particle agglutination (PA). Anti-Mycoplasma pneumoniae IgM in patients with respiratory tract infection was detected by indirect immunofluorescence. All patients were divided into 9 groups according to age: $\leq 1,2-3,4-6,7-14,15-$ $18,19-39,40-59,60-79, \geq 80$,

Results: The positive rate of Mycoplasma pneumoniae total antibody in 5,666 patients with community-acquired pneumonia was $40.13 \%$. In adults and children, the positive rates were $19.92 \%$ and $77.3 \%(p<0.05)$, respectively. The positive rates in males and females was $37.89 \%$ and $42.40 \%(p<0.05)$, respectively. The positive rate for anti-Mycoplasma pneumoniae IgM in 5,746 patients with respiratory tract infection was $28.56 \%$, and $10.37 \%$ and $36.82 \%$ in adults and children $(p<0.05)$, respectively. In males and females, the positive rate for anti-Mycoplasma pneumoniae lgM was $24.56 \%$ and $33.38 \%(p<0.05)$. The highest positive rates for total antibody and anti-Mycoplasma pneumoniae IgM were recorded in autumn. Of the 1,975 patients tested for Mycoplasma pneumoniae antibody using both methods simultaneously, $26.71 \%$ were negative for total antibody and $8.63 \%$ had titers ranging between 1:40 and 1:80 when positive for IgM antibody. When negative for antiMycoplasma pneumoniae IgM, total antibody titer was $\geq 1: 160$ in $34.94 \%$ of the patients.

Conclusion: Mycoplasma pneumoniae is the main cause of respiratory tract infection and its incidence is highest in autumn. Because Mycoplasma pneumoniae was more commonly detected in women and children, screening should be strengthened in these groups.

\section{Background}

Mycoplasma pneumonia (M. pneumoniae) is one of the main causes of respiratory tract infection and the main cause of CAP (community-acquired pneumonia) in children and adults ${ }^{1,2}$. M. pneumoniae incidence has increased in recent years, with an epidemic peak every few years and infection rates of up to $30 \%^{3-5}$. Because it can adhere to the surface of respiratory epithelial cells, M. pneumoniae triggers direct cytotoxicity. By triggering airway inflammation, it can also cause cell swelling and necrosis, leading to pharyngitis, bronchitis, or atypical pneumonia ${ }^{6-8}$. Its clinical manifestations are easily confused with those of other respiratory pathogens. Because it lacks cytoderm, $M$. pneumoniae is resistant to antimicrobial agents targeting the cytoderm, such as $\beta$-lactams), and is only sensitive to fluoroquinolones, macrolides, and tetracyclines ${ }^{9}$. M. pneumoniae resistance to an increasing number of macrolides has been reported in recent years ${ }^{10,11}$. Thus, rapid, and accurate diagnosis of $M$. pneumoniae infection is key to effective treatment.

M. pneumoniae is mainly detected through etiological and serological methods. Etiological detection includes culture, double antibody sandwich test ${ }^{12}$, and molecular biology methods. Serological detection includes ELISA, GICT (immune colloidal gold technique), CLIA (chemiluminescent immunoassay), IFA (indirect immunofluorescence assay), CFA (complement ratification assay), CAT (cold agglutination test), and PA (particle agglutination). In culture, isolated $M$. pneumoniae grows slowly, slowing its clinical diagnosis ${ }^{13}$, and although PCR is effective, it is complex, and difficult to deploy widely. Serological detection of $M$. pneumoniae is fast and more easily executed at clinics. Due to high high sensitivity and specificity, M. pneumoniae antibody detection is often used for diagnosis ${ }^{14,15}$.

To determine the rates of $M$. pneumoniae infection in patients with respiratory tract infection in North China, we carried out a retrospective study on the detection of M. pneumoniae IgM antibody and total antibody. The aim of this study was to understand the trend and prevalence of M. pneumoniae infection in different populations of North China, and to guide the choice of $M$. pneumoniae detection strategies and treatment. 


\section{Patients And Methods \\ Study population}

This study retrospectively analyzed cases with symptoms, signs, and chest radiographs consistent with CAP that were examined at Second Affiliated Hospital of Tianjin University of Traditional Chinese Medicine between September 2017 and May 2021. Pneumonia was defined by the presence of fever, acute respiratory symptoms like cough, tachypnoea, difficult breathing, and presence of new infiltrate on chest radiography or consolidation not attributable to some etiologies. The study included 5,666 patients, who were tested for total $M$. pneumoniae antibodies by particle agglutination (PA), 5,746 patients who were tested for M. pneumoniae IgM antibodies by IFA, and 1,975 patients whose sera were tested for total $M$. pneumoniae antibodies and $M$. pneumoniae IgM antibodies using the methods above. The study was approved by the ethics committee of the Second Affiliated Hospital of Tianjin University of Traditional Chinese Medicine. Written informed consents were obtained from all the children's parents or guardian.

\section{PA and IFA methods}

Total M. pneumoniae antibody was evaluated by PA for the presence of IgG and IgM. Blood samples $(2 \mathrm{~mL})$ from patients were obtained. After centrifugation, serum were detected using the passive agglutination test (Serodia-Myco II kit, Fujirebio, Tokyo, Japan). Titers of 1:40 or more were reported as positive for the M. pneumoniae total antibody.

M. pneumoniae IgM antibodies were tested by IFA. Blood samples $(2 \mathrm{~mL})$ from patients were obtained.After centrifugation, serum were detected using the Pneumo slide IgM test (Vircell, Granada, Spain). Serum samples were then diluted at 1:2 PBS and treated with anti-human IgG sorbent. They were then added to every well containing the Pneumoslide IgM slide and incubated for 90 minutes at $37^{\circ} \mathrm{C}$. The slide was then washed twice with PBS and dried. The fluorescent secondary antibody was added and incubated for 30 minutes at $37^{\circ} \mathrm{C}$. The slide was then washed twice with PBS and observed by fluorescence microscopy. Apple green fluorescence signal in the periphery of the cell indicated that samples were positive for $M$. pneumoniae.

\section{Statistical Analysis}

Data were analyzed using SPSS 22.0. The Chi-square test was used to compare positive rates between different groups. $P<$ 0.05 indicated statistical significance.

\section{Results}

\section{Positive rate of total M. pneumoniae antibodies in adults and children with CAP}

The positive rate of total M. pneumoniae antibodies in the 5,666 patients with CAP was $40.13 \%(2274 / 5666$, Table 1$)$. The positive rates in adults $(19.92 \%, 731 / 3670)$ was significantly lower than in children $(77.30 \%, 1543 / 1996)\left(\chi^{2}=1772.042, p=\right.$ 0.000). The positive rate was significantly lower in males $(37.89 \%, 1080 / 2850)$ than females $(42.40 \%, 1194 / 2816)\left(\chi^{2}=\right.$ $11.969, p=0.001)$. In the adult group, the positive rate was significantly lower in males vs females $(16.75 \%, 306 / 1827$ vs $\left.23.06 \%, 425 / 1843, \chi^{2}=22.993, p=0.000\right)$. In children, the positive rate in males vs females did not differ significantly $(75.66 \%$, $774 / 1023$ vs $79.03 \%, 769 / 973, \chi^{2}=3.236, p=0.072$ ). The positive rate of total $M$. pneumoniae antibodies among children and adults was statistically significant. The positive rate of total $M$. pneumoniae antibodies among children was statistically significant $(X 2=87.350, P=0.000)$, and the highest positive rate was $86.46 \%$ in children aged $7-14$ years (group 4$)$. The positive rate of total M. pneumoniae antibodies in adults was statistically significant $\left(\chi^{2}=268.818, p=0.000\right)$, and the highest positive rate was $42.16 \%$ in adults aged 19-39 (group 1). The positive rate in male vs female children in group 1 and 3 , and adults in group 1 and 3 was statistically significant, $(p=<0.05)$. 
Table 1

The positive rate of M. pneumoniae total antibody and Anti-Mycoplasma pneumoniae IgM in adults and children with CAP

\begin{tabular}{|c|c|c|c|c|c|c|c|c|}
\hline \multicolumn{3}{|c|}{ Characteristic } & \multicolumn{3}{|c|}{ M. pneumoniae total antibody } & \multicolumn{3}{|c|}{ Anti- M. pneumoniae IgM } \\
\hline & & & \multirow{2}{*}{$\begin{array}{l}\text { positive rate } \\
\text { (positive } \\
\text { /total) }\end{array}$} & \multicolumn{2}{|c|}{ positive rate (positive / total) } & \multirow{2}{*}{$\begin{array}{l}\text { positive rate } \\
\text { (positive } \\
\text { /total) }\end{array}$} & \multicolumn{2}{|c|}{$\begin{array}{l}\text { positive rate (positive / } \\
\text { total) }\end{array}$} \\
\hline & & & & male & female & & male & female \\
\hline & & & $\begin{array}{l}40.13 \% \\
(2274 / 5666)\end{array}$ & $\begin{array}{l}37.89 \% \\
(1080 / 2850)\end{array}$ & $\begin{array}{l}42.40 \% \\
(1194 / 2816) *\end{array}$ & $\begin{array}{l}28.56 \% \\
(1641 / 5746)\end{array}$ & $\begin{array}{l}24.56 \% \\
(772 / 3143)\end{array}$ & $\begin{array}{l}33.38 \% \\
(869 / 2603) \star\end{array}$ \\
\hline Adults & & & $\begin{array}{l}19.92 \% \\
(731 / 3670)\end{array}$ & $\begin{array}{l}16.75 \% \\
(306 / 1827)\end{array}$ & $\begin{array}{l}23.06 \% \\
(425 / 1843)^{\star}\end{array}$ & $\begin{array}{l}10.37 \% \\
(186 / 1794)\end{array}$ & $\begin{array}{l}9.57 \% \\
(99 / 1035)\end{array}$ & $\begin{array}{l}11.46 \% \\
(87 / 759)\end{array}$ \\
\hline Children & & & $\begin{array}{l}77.30 \% \\
(1543 / 1996)\end{array}$ & $\begin{array}{l}75.66 \% \\
(774 / 1023)\end{array}$ & $\begin{array}{l}79.03 \% \\
(769 / 973)\end{array}$ & $\begin{array}{l}36.82 \% \\
(1455 / 3952)\end{array}$ & $\begin{array}{l}31.93 \% \\
(673 / 2108)\end{array}$ & $\begin{array}{l}42.41 \% \\
(782 / 1844)^{*}\end{array}$ \\
\hline \multirow[t]{2}{*}{$\chi^{2}$} & & & $1772.042^{\star *}$ & $1741.505^{\star \star}$ & $175.944^{\star \star}$ & 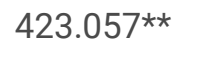 & $187.318^{\star \star}$ & $273.663^{\star \star}$ \\
\hline & & Age & & & & & & \\
\hline \multirow[t]{5}{*}{ Children } & $\begin{array}{l}\text { Group } \\
1\end{array}$ & $\leq 1$ & $\begin{array}{l}58.82 \% \\
(10 / 17)\end{array}$ & $\begin{array}{l}80.00 \% \\
(8 / 10)\end{array}$ & $\begin{array}{l}28.57 \% \\
(2 / 7)^{\star}\end{array}$ & $\begin{array}{l}30.63 \% \\
(49 / 160)\end{array}$ & $\begin{array}{l}27.38 \% \\
(23 / 84)\end{array}$ & $\begin{array}{l}34.21 \% \\
(26 / 76)\end{array}$ \\
\hline & $\begin{array}{l}\text { Group } \\
2\end{array}$ & $2-3$ & $\begin{array}{l}63.49 \% \\
(193 / 304)\end{array}$ & $\begin{array}{l}63.19 \% \\
(91 / 144)\end{array}$ & $\begin{array}{l}63.75 \% \\
(102 / 160)\end{array}$ & $\begin{array}{l}40.29 \% \\
(498 / 1236)\end{array}$ & $\begin{array}{l}35.61 \% \\
(235 / 660)\end{array}$ & $\begin{array}{l}45.66 \% \\
(263 / 576)^{\star}\end{array}$ \\
\hline & $\begin{array}{l}\text { Group } \\
3\end{array}$ & $4-6$ & $\begin{array}{l}72.87 \% \\
(529 / 726)\end{array}$ & $\begin{array}{l}69.71 \% \\
(267 / 383)\end{array}$ & $\begin{array}{l}76.38 \% \\
(262 / 343)^{\star}\end{array}$ & $\begin{array}{l}37.89 \% \\
(532 / 1404)\end{array}$ & $\begin{array}{l}32.98 \% \\
(250 / 758)\end{array}$ & $\begin{array}{l}43.65 \% \\
(282 / 646)^{\star}\end{array}$ \\
\hline & $\begin{array}{l}\text { Group } \\
4\end{array}$ & $7-14$ & $\begin{array}{l}86.46 \% \\
(760 / 879)\end{array}$ & $\begin{array}{l}85.40 \% \\
(386 / 452)\end{array}$ & $\begin{array}{l}87.59 \% \\
(374 / 427)\end{array}$ & $\begin{array}{l}33.17 \% \\
(338 / 1019)\end{array}$ & $\begin{array}{l}27.98 \% \\
(148 / 529)\end{array}$ & $\begin{array}{l}38.78 \% \\
(190 / 490)^{*}\end{array}$ \\
\hline & $\begin{array}{l}\text { Group } \\
5\end{array}$ & $\begin{array}{l}15- \\
18\end{array}$ & $\begin{array}{l}72.86 \% \\
(51 / 70)\end{array}$ & $\begin{array}{l}64.71 \% \\
(22 / 34)\end{array}$ & $\begin{array}{l}80.56 \% \\
(29 / 36)\end{array}$ & $\begin{array}{l}29.57 \% \\
(38 / 133)\end{array}$ & $\begin{array}{l}22.08 \% \\
(17 / 77)\end{array}$ & $\begin{array}{l}37.50 \% \\
(21 / 56)\end{array}$ \\
\hline \multirow[t]{4}{*}{ Adults } & $\begin{array}{l}\text { Group } \\
1\end{array}$ & $\begin{array}{l}19- \\
39\end{array}$ & $\begin{array}{l}42.16 \% \\
(234 / 555)\end{array}$ & $\begin{array}{l}36.21 \% \\
(84 / 232)\end{array}$ & $\begin{array}{l}46.44 \% \\
(150 / 323)^{\star}\end{array}$ & $\begin{array}{l}29.79 \% \\
(84 / 282)\end{array}$ & $\begin{array}{l}26.38 \% \\
(43 / 163)\end{array}$ & $\begin{array}{l}34.45 \% \\
(41 / 119)\end{array}$ \\
\hline & $\begin{array}{l}\text { Group } \\
2\end{array}$ & $\begin{array}{l}40- \\
59\end{array}$ & $\begin{array}{l}26.79 \% \\
(165 / 616)\end{array}$ & $\begin{array}{l}23.14 \% \\
(59 / 255)\end{array}$ & $\begin{array}{l}29.36 \% \\
(106 / 361)\end{array}$ & $\begin{array}{l}6.64 \% \\
(16 / 241)\end{array}$ & $\begin{array}{l}6.72 \% \\
(9 / 134)\end{array}$ & $\begin{array}{l}6.54 \% \\
(7 / 107)\end{array}$ \\
\hline & $\begin{array}{l}\text { Group } \\
3\end{array}$ & $\begin{array}{l}60- \\
79\end{array}$ & $\begin{array}{l}15.15 \% \\
(245 / 1617)\end{array}$ & $\begin{array}{l}13.61 \% \\
(126 / 926)\end{array}$ & $\begin{array}{l}17.22 \% \\
(119 / 691)^{*}\end{array}$ & $\begin{array}{l}7.18 \% \\
(58 / 808)\end{array}$ & $\begin{array}{l}7.4 \% \\
(37 / 500)\end{array}$ & $\begin{array}{l}6.82 \% \\
(21 / 308)\end{array}$ \\
\hline & $\begin{array}{l}\text { Group } \\
4\end{array}$ & $\geq 80$ & $\begin{array}{l}9.89 \% \\
(87 / 880)\end{array}$ & $\begin{array}{l}8.94 \% \\
(37 / 414)\end{array}$ & $\begin{array}{l}10.73 \% \\
(50 / 466)\end{array}$ & $\begin{array}{l}6.05 \% \\
(28 / 463)\end{array}$ & $\begin{array}{l}4.20 \% \\
(10 / 238)\end{array}$ & $\begin{array}{l}8.00 \% \\
(18 / 225)\end{array}$ \\
\hline \multicolumn{3}{|l|}{$x^{2}$} & $2013.119 * \star$ & $1058.719 * *$ & $968.942 * \star$ & $507.277^{\star \star \star}$ & 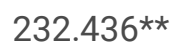 & $274.175^{\star \star}$ \\
\hline
\end{tabular}

The positive rate of M. pneumoniae IgM antibodies in adults and children with CAP

The positive rate of M. pneumoniae lgM antibody in the 5,746 patients with respiratory tract infection was $28.56 \%$ (Table 1 ). The positive rate in adults $(10.37 \%, 186 / 1794)$ was significantly lower than in children $(36.82 \%, 1455 / 3952)\left(\chi^{2}=423.057, p=\right.$ $0.000)$. The positive rate in males $(24.56 \%, 772 / 3143)$ was significantly lower than in females $(33.38 \%, 869 / 2603)\left(\chi^{2}=\right.$ $54.313, p=0.000)$. In adults, the positive rate in males vs females $(9.57 \%, 99 / 1035$ vs $11.46 \%, 87 / 759)$ did not differ significantly $\left(\chi^{2}=1.696, p=0.193\right)$. In children, the positive rate was significantly lower in males vs females $(31.93 \%$, $673 / 2108$ vs $42.41 \%, 782 / 1844)\left(\chi^{2}=46.456, p=0.000\right)$. The positive rate of $M$. pneumoniae IgM antibody among children and adults was statistically significant. The positive rate of $\operatorname{lgM}$ antibody in children group was statistically significant $\left(\chi^{2}=\right.$ 
$19.462, p=0.001$ ), and the highest positive rate was $40.29 \%$ in children aged $2-3$ years (group 2 ). The positive rate of IgM antibody in the adult group was statistically significant $(\chi 2=268.818, P=0.000)$, and the highest positive rate was $29.79 \%$ in adults aged 19-39 years (group 1). The positive rate in male and female children in group 2, 3, and 4 was statistically significant $(p=<0.05)$.

\section{M. pneumoniae infection trends in North China}

The positive rates of total M. pneumoniae antibody and IgM antibody in each year and season between September 2017 and May 2021 are shown in Table 2-3 and Fig. 1. 2019 had the highest positive rate. In each year, the highest positive rate of total M. pneumoniae antibodies were recorded in autumn, with the highest and lowest positive rates recorded in the autumn of 2019 (66.67\%), and spring of 2020 (19.18\%), respectively. The positive rate of M. pneumoniae IgM antibody was highest in autumn except for 2018, when it was highest in winter. The highest and lowest positive rates were recorded in autumn 2019 (44.29\%) and spring 2020 (6.72\%), respectively.

Table 2

The positive rate of $M$. pneumoniae antibody in each year between 2017 and 2021

\begin{tabular}{|lllllll|}
\hline Year & \multicolumn{3}{c}{ M. pneumoniae total antibody } & \multicolumn{3}{c|}{ Anti- M. pneumoniae IgM } \\
\cline { 2 - 7 } & Total & Positive & positive rate & Total & Positive & positive rate \\
\hline 2017 & 663 & 232 & $34.99 \%$ & 933 & 279 & $29.90 \%$ \\
\hline 2018 & 1811 & 670 & $37.00 \%$ & 1710 & 470 & $27.49 \%$ \\
\hline 2019 & 1855 & 923 & $49.76 \%$ & 1782 & 692 & $38.83 \%$ \\
\hline 2020 & 843 & 301 & $35.71 \%$ & 818 & 109 & $13.33 \%$ \\
\hline 2021 & 494 & 148 & $29.96 \%$ & 503 & 91 & $18.09 \%$ \\
\hline
\end{tabular}


Table 3

The positive rate of MP antibody in each season between 2017 and 2021

\begin{tabular}{|c|c|c|c|c|c|c|c|}
\hline & \multirow[t]{2}{*}{ Season } & \multicolumn{3}{|c|}{ M. pneumoniae total antibody } & \multicolumn{3}{|c|}{ Anti- M. pneumoniae IgM } \\
\hline & & Total & Positive & positive rate & Total & Positive & positive rate \\
\hline \multirow[t]{2}{*}{2017} & Autumn & 454 & 176 & $38.77 \%$ & 737 & 214 & $29.04 \%$ \\
\hline & Winter & 548 & 125 & $22.81 \%$ & 549 & 157 & $28.60 \%$ \\
\hline \multirow[t]{4}{*}{2018} & Spring & 380 & 120 & $31.58 \%$ & 419 & 101 & $24.11 \%$ \\
\hline & Summer & 410 & 152 & $37.07 \%$ & 294 & 82 & $27.89 \%$ \\
\hline & Autumn & 523 & 276 & $52.77 \%$ & 430 & 124 & $28.84 \%$ \\
\hline & Winter & 433 & 133 & $30.72 \%$ & 528 & 200 & $37.88 \%$ \\
\hline \multirow[t]{4}{*}{2019} & Spring & 404 & 161 & $39.85 \%$ & 448 & 158 & $35.27 \%$ \\
\hline & Summer & 364 & 167 & $45.88 \%$ & 354 & 132 & $37.29 \%$ \\
\hline & Autumn & 534 & 356 & $66.67 \%$ & 439 & 212 & $48.29 \%$ \\
\hline & Winter & 489 & 267 & $54.60 \%$ & 426 & 95 & $22.30 \%$ \\
\hline \multirow[t]{4}{*}{2020} & Spring & 146 & 28 & $19.18 \%$ & 119 & 8 & $6.72 \%$ \\
\hline & Summer & 205 & 61 & $29.76 \%$ & 212 & 21 & $9.91 \%$ \\
\hline & Autumn & 180 & 69 & $38.33 \%$ & 177 & 29 & $16.38 \%$ \\
\hline & Winter & 262 & 74 & $28.24 \%$ & 268 & 38 & $14.18 \%$ \\
\hline 2021 & Spring & 334 & 109 & $32.63 \%$ & 346 & 70 & $20.23 \%$ \\
\hline
\end{tabular}

Analysis of the consistency between M. pneumoniae total antibody M. pneumoniae IgM antibody in adult and children with CAP

In the 1,975 cases positive for M. pneumoniae IgM antibody, $26.71 \%$ were negative for total antibody, and $8.63 \%$ had a titer range of 1:40 - 1:80. Of the cases that were negative for anti- $M$. pneumoniae IgM antibody, $34.94 \%$ had a total antibody titer $\geq 1: 160$ (Table 4). 
Table 4

The corresponding IgM antibody at different titers of total MP antibody between 2017 and 2021

\begin{tabular}{|c|c|c|c|c|c|c|c|c|c|c|c|c|c|}
\hline \multicolumn{14}{|c|}{ M. pneumoniae total antibody } \\
\hline \multirow{5}{*}{$\begin{array}{l}\text { Anti- } M \text {. } \\
\text { pneumoniae } \\
\operatorname{lgM}(+)\end{array}$} & \multirow{2}{*}{$\begin{array}{l}\text { Titers } \\
\text { Characteristic }\end{array}$} & \multicolumn{2}{|c|}{$1: 40-1 \otimes 80$} & \multicolumn{2}{|c|}{$1: 160$} & \multicolumn{2}{|c|}{ 1: 320} & \multicolumn{2}{|c|}{$1: 640$} & \multicolumn{2}{|c|}{ 1: 1280} & \multicolumn{2}{|l|}{ प्र } \\
\hline & & $\mathrm{n}$ & $\%$ & $\mathrm{n}$ & $\%$ & $\mathrm{n}$ & $\%$ & $\mathrm{n}$ & $\%$ & $\mathrm{n}$ & $\%$ & $\mathrm{n}$ & $\%$ \\
\hline & & 43 & 8.63 & 32 & 6.43 & 25 & 5.02 & 35 & 7.03 & 230 & 46.18 & 133 & 26.71 \\
\hline & Adults & 9 & 11.11 & 4 & 4.94 & 3 & 3.70 & 0 & 0 & 5 & 6.17 & 60 & 74.07 \\
\hline & Children & 34 & 8.15 & 28 & 6.71 & 22 & 5.28 & 35 & 8.39 & 225 & 45.18 & 73 & 17.51 \\
\hline \multicolumn{14}{|c|}{ M. pneumoniae total antibody } \\
\hline \multirow{5}{*}{$\begin{array}{l}\text { Anti- } M \text {. } \\
\text { pneumoniae } \\
\text { IgM }(-)\end{array}$} & Titers & \multicolumn{2}{|c|}{ 1: $40-1 \rrbracket 80$} & \multicolumn{2}{|c|}{ 1: 160} & \multicolumn{2}{|c|}{ 1: 320} & \multicolumn{2}{|c|}{$1: 640$} & \multicolumn{2}{|c|}{ 1: 1280} & \multicolumn{2}{|l|}{ प्र } \\
\hline & Characteristic & $\mathrm{n}$ & $\%$ & $\mathrm{n}$ & $\%$ & $\mathrm{n}$ & $\%$ & $\mathrm{n}$ & $\%$ & $\mathrm{n}$ & $\%$ & $\mathrm{n}$ & $\%$ \\
\hline & & 129 & 8.73 & 85 & 5.75 & 61 & 4.13 & 60 & 4.06 & 310 & 20.99 & 832 & 56.33 \\
\hline & Adults & 75 & 9.35 & 31 & 3.87 & 15 & 18.70 & 3 & 0.37 & 14 & 1.75 & 664 & 82.79 \\
\hline & Children & 54 & 8.00 & 54 & 8.00 & 46 & 6.81 & 57 & 8.44 & 296 & 43.85 & 168 & 24.89 \\
\hline
\end{tabular}

\section{Discussion}

M. pneumoniae is a common pathogen that mainly causes human respiratory tract infections. This study retrospectively analyzed data on 5,666 respiratory tract infection cases where total M. pneumoniae antibody was detected using the PA method and 5,746 cases where M. pneumoniae IgM antibody was detected using IFA. The results showed that the positive rate of total M. pneumoniae antibody in the 5,666 respiratory patients was $40.13 \%$, which was higher than the $27.20 \%$ reported by Huang Haiying ${ }^{16}$ in Guangzhou. The positive detection rate in children was much higher than in adults, and also higher than that reported in relevant literature. When children are admitted at our hospital with suspected M. pneumoniae infection, blood is first collected using the finger prick method due to difficulty collecting venous blood, and GICT(immune colloidal gold technique), used for primary screening. Children cases in which antibody titer is detected using PA were initially positive or weakly positive based on GICT, thus the positive rate was higher than that of adults and other areas. Of the 41,230 children tested for M. pneumoniae antibody using GICT, 8,825 (21.40\%) were positive, which is consistent with previous reports.

The positive rate of M. pneumoniae antibody in females (42.40\%) was higher in males (37.89\%), which is consistent with previous reports ${ }^{4}$.The positive rate of total $M$. pneumoniae antibody in children increased with age, with the highest positive rate detected in 7-14 year-olds. In adults the highest positive rates were detected in 19-39 year-olds. It is reported that people with low and defective immune function and infants with low ability to produce antibodies may fail to produce antibodies or produce them at low titers ${ }^{17}$. This may be due to the immature immune system of infants, insufficient antibody generation after initial infection with M. pneumoniae, limited movement by infants, and less chance of M. pneumoniae infection, which affects the detection of total anti-M. pneumoniae antibody. Children aged 7-14 years gradually develop immunity and increase their range of activity in places like schools, and adults aged 19-39 have complete immune systems and spend longer in schools and workplaces. Thus, they have a higher increased chance of cross-infection with M. pneumoniae. After repeated infection with $M$. pneumoniae, the antibody titer increased gradually, which increased the positive rate of total antibody. The positivity rate for $M$. pneumoniae falls with increasing age, probably due to gradual weakening of the immune system with advancing age and fewer opportunities for elderly people to go out. Thus, screening for M. pneumoniae total antibody in preschool and school-age children should be strengthened. 
The positive detection rate of $M$. pneumoniae IgM antibody in 5,746 respiratory patients was $28.56 \%$, which is slightly lower than reported in Ningbo city ${ }^{18}$. The positive rate was $10.37 \%$ in adults and $36.8 \%$ in children. The positive rate was highest in 2-3 year-olds, and highest in 19-39 year-olds. IgM levels generally start rising a week after infection, peaking in 2-3 weeks, before starting to fall in 4 weeks and reaching minimum levels $2-3$ months after infection ${ }^{19}$. IgA antibody levels rose rapidly in the early stage of $M$. pneumoniae infection, peaked at 7-14 days, and fell back earlier. IgG rises 14 days after infection and generally peaks 5 weeks after infection, and is persistent ${ }^{20}$. The positive rate of $M$. pneumoniae lgM antibody in each group was lower than the total antibody positive rate. IgM antibody is a diagnostic index for early M. pneumoniae infection and its detection can allow early diagnosis. Thus, clinicians should consider M. pneumoniae as the main respiratory tract infection in children and adolescents, especially in early childhood and pre-school age.

Analysis of annual and seasonal M. pneumoniae total antibody and IgM levels revealed that they were highest in 2019. The $M$. pneumoniae antibody positive rate was highest in autumn each year, which is the same as the peak of incidence in Hebei Province(China) ${ }^{21}$. The fall of 2019 was the highest, and the spring of 2020 was the lowest, which was related to the COVID19 outbreak. From then on, people in China wearing masks and going out less. Infected people are the main source of $M$. pneumoniae infection. It is suggested that reducing cross infection and good protection can reduce M. pneumoniae infection rates.

In the 1,975 CAP patients tested for $M$. pneumoniae antibody using particle agglutination and indirect immunofluorescence when the M. pneumoniae IgM antibody was negative, $34.94 \%$ of the patients had a total antibody titer $\geq 1: 160$. This suggests that testing for M. pneumoniae IgM antibody alone misses some $M$. pneumoniae infections. A negative serum IgM antibody result does not rule out acute infection. In cases that were positive for $M$. pneumoniae IgM antibody, $26.71 \%$ were negative for M. pneumoniae total antibody. Probably because in the early phases of infection, IgM is quickly generated but not IgG, which fails to meet the reagent methodological judgment standards. It may also be related to methodological sensitivity. IFA uses a two-step method, and its sensitivity is better amplified by reaction with a fluorescent binder, whereas PA is slightly less sensitive than IFA. The total antibody titer in $8.63 \%$ of the patients was between 1:40 and 1:80. "Expert consensus on laboratory diagnostics and clinical practice of Mycoplasma pneumoniae infection in children in China (2019) ${ }^{22}$ and other research recommends that PA antibody titers $\geq 1: 160$ indicate a recent or present infection ${ }^{20,23}$. It is suggested that we should simultaneously detect IgM antibody and dynamically monitor changes in total antibody titer for this population. This may enhance sensitivity and specificity in M. pneumoniae diagnosis and minimize missed diagnoses.

\section{Conclusions}

M. pneumoniae is the main cause of respiratory tract infection and its positive rate is higher in women and children of Tianjin. Thus, detection of respiratory tract infections in these groups should be strengthened. Autumn is the season of high incidence of $M$. pneumoniae in North China. Strengthening protection and reducing cross infection may reduce M. pneumoniae infection. Simultaneous detection of IgM antibody and dynamically monitoring total antibody titers can improve $M$. pneumoniae detection and minimize missed diagnoses.

\section{Declarations}

\section{Acknowledgments}

We would like to express our gratitude to all of the subjects who participated in this study..

\section{Author Contributions}

Conceived and designed the experiments: Li Ren and Xuehong Wen.

Performed the experiments: Jupeng Wang, Lina Zhu, Mingkun Ma, Guangye Wu and Shaohong Li. 
Drafted and wrote the final version of the manuscrip: Jupeng Wang and Lina Zhu.

Guidelines for clinical diagnosis: Hui Chen, Suxiang Guo.

All authors read and approved the final manuscript.

\section{Funding}

This study was supported by Scientific Research Program of Tianjin Education Commission (\#2019KJ045) and the National Natural Science Foundation of China (\#81904250).

\section{Availability of data and materials}

The access to datasets generated and/or analyzed during the current study is not publicly available due to the hospital's research policy to guarantee the privacy of the participants, whose research data are confidential. Aggregate analyses are however available on reasonable request to the corresponding author.

\section{Ethics approval and consent to participate}

An informed, written consent was obtained from all parents/guardians prior to including the patients in the study.

\section{Consent for publication}

Not applicable.

\section{Competing Interest}

The authors have declared no conflict of interest.

\section{References}

1. Liu YF, Gao Y, Chen MF, et al. Etiological analysis and predictive diagnostic model building of community-acquired pneumonia in adult outpatients in Beijing, China. (1471-2334 (Electronic)).

2. McCulloh RJ, Patel K. Recent Developments in Pediatric Community-Acquired Pneumonia. Curr Infect Dis Rep. 2016;18(5):14.

3. Chaudhry R, Ghosh A, Chandolia A. Pathogenesis of Mycoplasma pneumoniae: An update. Indian J Med Microbiol. 2016;34(1):7-16.

4. Yan C, Sun H, Zhao H. Latest Surveillance Data on Mycoplasma pneumoniae Infections in Children, Suggesting a New Epidemic Occurring in Beijing. J Clin Microbiol. 2016;54(5):1400-1.

5. Dumke R, Schnee C, Pletz MW, et al. Mycoplasma pneumoniae and Chlamydia spp. infection in community-acquired pneumonia, Germany, 2011-2012. Emerg Infect Dis. 2015;21(3):426-34.

6. Valade S, Biard L, Lemiale V, et al. Severe atypical pneumonia in critically ill patients: a retrospective multicenter study. Ann Intensive Care. 2018;8(1):81.

7. Wang X, Zhong LJ, Chen ZM, et al. Necrotizing pneumonia caused by refractory Mycoplasma pneumonia pneumonia in children. World J Pediatr. 2018;14(4):344-49.

8. Canavan TN, Mathes EF, Frieden I, et al. Mycoplasma pneumoniae-induced rash and mucositis as a syndrome distinct from Stevens-Johnson syndrome and erythema multiforme: a systematic review. J Am Acad Dermatol. 2015;72(2):23945.

9. Dumke R, Benitez AJ, Chalker V, et al. Multi-center evaluation of one commercial and 12 in-house real-time PCR assays for detection of Mycoplasma pneumoniae. Diagn Microbiol Infect Dis. 2017;88(2):111-14. 
10. Zhou Z, Li X, Chen X, et al. Macrolide-resistant Mycoplasma pneumoniae in adults in Zhejiang, China. Antimicrob Agents Chemother. 2015;59(2):1048-51.

11. Zhang Y, Zhou Y, Li S, Yang D, et al. The Clinical Characteristics and Predictors of Refractory Mycoplasma pneumoniae Pneumonia in Children. PLoS One. 2016;11(5):e0156465.

12. Li W, Liu Y, Zhao Y, et al. Shang S. Rapid diagnosis of Mycoplasma pneumoniae in children with pneumonia by an immuno-chromatographic antigen assay. Sci Rep. 2015;5:15539.

13. Waites KB, Talkington DF. Mycoplasma pneumoniae and its role as a human pathogen. Clin Microbiol Rev. 2004;17(4):697-728. table of contents.

14. She RC, Thurber A, Hymas WC, et al. Limited utility of culture for Mycoplasma pneumoniae and Chlamydophila pneumoniae for diagnosis of respiratory tract infections. J Clin Microbiol. 2010;48(9):3380-82.

15. Chen K, Xu W, Yang C. Comparison of Indirect Immunofluorescence and Passive Particle Agglutination for the Detection of Mycoplasma Pneumoniae Antibodies. Clin Lab. 2019;65(3).

16. Huang HY, Zhou Q, Jia HY, et al. Epidemiological survey of Mycoplasma pneumoniae infection in different populations in Guangzhou area. Chin J Nosocomiol. 2015;25(2):300-2.

17. Zhao F, Liu L, Tao X, et al. Zhang J. Culture-Independent Detection and Genotyping of Mycoplasma pneumoniae in Clinical Specimens from Beijing, China. PLoS One. 2015;10(10):e0141702.

18. Chen M, Fan ML, Zhu SP. Epidemiological characteristics of Mycoplasma pneumoniae infections, in Yinzhou area of Ningbo during 2009-2011. 23. 2013;17:4219-31.

19. Lee SC, Youn YS, Rhim JW, et al. Early Serologic Diagnosis of Mycoplasma pneumoniae Pneumonia: An Observational Study on Changes in Titers of Specific-IgM Antibodies and Cold Agglutinins. Med (Baltim). 2016;95(19):e3605.

20. Lee WJ, Huang EY, Tsai CM, et al. Role of Serum Mycoplasma pneumoniae IgA, IgM, and IgG in the Diagnosis of Mycoplasma pneumoniae-Related Pneumonia in School-Age Children and Adolescents. Clin Vaccine Immunol. 2017;24(1).

21. Wang L, Feng Z, Zhao M, et al. A comparison study between GeXP-based multiplex-PCR and serology assay for Mycoplasma pneumoniae detection in children with community acquired pneumonia. BMC Infect Dis. 2017;17(1):518.

22. [Expert consensus on laboratory diagnostics and clinical practice. of Mycoplasma pneumoniae infection in children in China (2019)]. Zhonghua Er Ke Za Zhi. 2020;58(5):366-73.

23. Matas L, Dominguez J, De Ory F, et al. Evaluation of Meridian ImmunoCard Mycoplasma test for the detection of Mycoplasma pneumoniae-specific IgM in paediatric patients. Scand J Infect Dis. 1998;30(3):289-93.

\section{Figures}



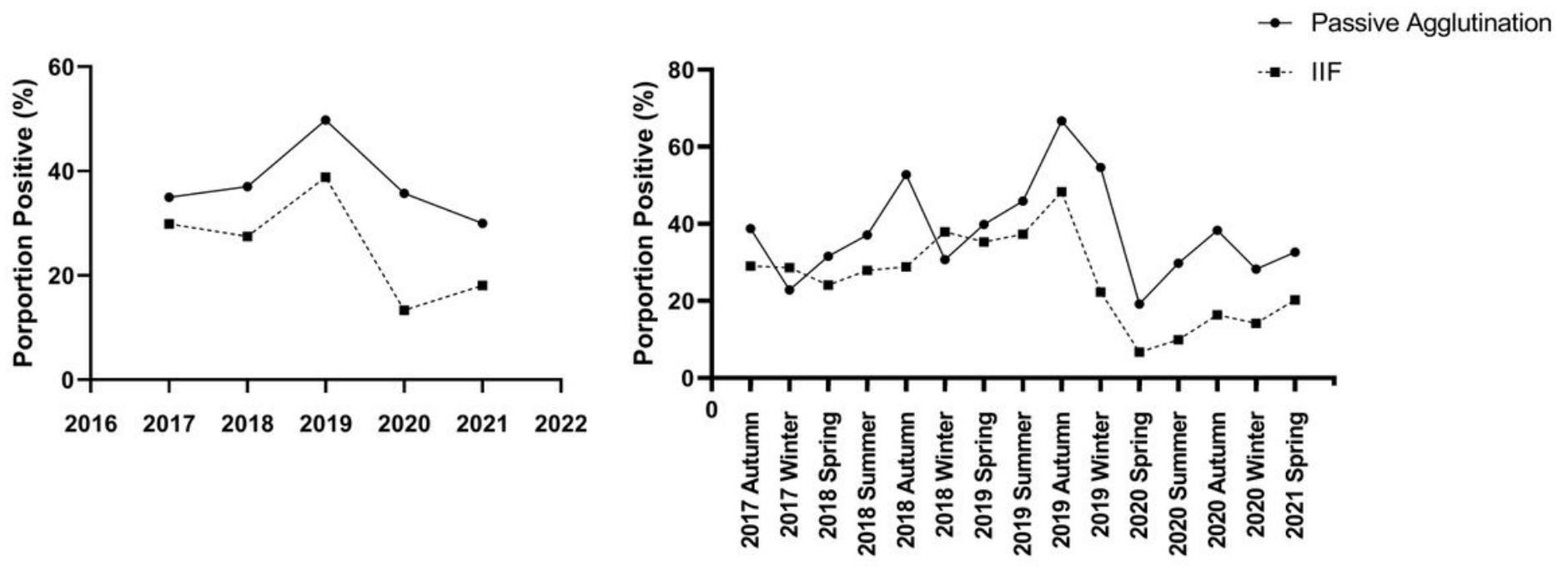

Figure 1

The positive rates of M. pneumoniae total antibody and anti-M. pneumoniae IgM in each year and season betweenr 2017 and 2021 